Przegląd Badań Edukacyjnych Educational Studies Review

ISSN 1895-4308

nr 27 (2/2018), s. 51-70

ORYGINALNE ARTYKULY BADAWCZE

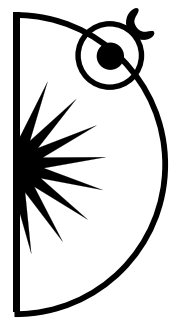

Dorota Moroń

ORCID iD: 0000-0002-9242-7305

University of Wroclaw, dorota.moron@uwr.edu.pl

Agnieszka Makarewicz-Marcinkiewicz

ORCID iD: 0000-0002-0501-4810

University of Wroclaw, agnieszka.makarewicz-marcinkiewicz@uwr.edu.pl

\title{
Higher Education Market Formation in Post- Transformation European Countries. Public and Non-Public Schools in the Higher Education Systems of Poland, the Czech Republic and Romania
}

http://dx.doi.org/10.12775/PBE.2018.016

\begin{abstract}
The article discusses the problem of creating of a higher education market in post-communist countries in the period of transformation. On the examples of three countries: Poland, the Czech Republic and Romania, the implementation of multi-sectoral social policy paradigm, allowed to show that liberalization of the higher education system was a response to market demand and led to the creation of a model in which both public and private universities operate, and the sources of funding for higher education are also public and private. Due to the growing interest in higher education during the transformation period and the inability to satisfy educational aspirations by the public sector, the countries introduced a market element to higher education, allowing for the functioning of non-public schools. It brought positive effects related to the expansion of the educational offer, but also negative, such as lowering the quality of education.
\end{abstract}

Key words: higher education institutions, public higher education institutions, non-public higher education institutions, multisectorality, education market. 


\section{Introduction}

The higher education option is gaining particular importance and prominence in today's society due to the shrinking number of job offers for people with low qualifications and the growing demand for highly qualified specialists. This requires extending the educational offer of higher-education institutions both in terms of the offered fields of studies as well as the number of places for students.

The fact that such education policy is acquiring more importance does not mean that public authorities are obliged to maintain the entire educational structure. The multi-sectoral approach to education, i.e. schools run by the government as well as the private and non-governmental sectors, is justified also by the desire for extended educational offerings which are adjusted to meet students' and learners' expectations. By acknowledging that students are free to choose their school and take advantage of additional, appropriately specialised classes, this approach is further substantiated.

The reforms conducted worldwide indicate a similar trend towards a market-based approach to higher education (Amaral, 2012; Marginson, 2007; Bok, 2004; Neave, 2012; Neave, 1998; Potulicka, 1996, 2010; Teixeira, Dill, 2011). What is changing is the role of the state, with regard to public as well as nonpublic universities (Heller, 2011; Lovell et. al., 2012), and especially, the principles of financing higher education (Neave, 2012; Paulsen, Smart 2002; Weisbrod et. al., 2008). As Alberto Amaral (2012, p. IX) emphasises: "These reforms present some common trends - increasing institutional autonomy, reinforced power of central administration, decreasing collegiality and changing quality systems from improving accreditation to diversifying funding sources".

Similar processes are taking place in post-communist countries, yet with a certain delay resulting from the prior operation of undemocratic systems. In these countries, the processes are linked with general reforms in individual spheres of social policy (Reisz, 2007). The need to reform higher education in Poland, the Czech Republic and Romania resulted not only from internal factors but external trends and circumstances, specifically related to joining the Bologna Process.

This article aims to analyse the formation of the higher education market in Poland, the Czech Republic and Romania. Their higher education systems had been shaped by over 40 years of the communist rule and its social policy, including education policy, and only began to see development after the reforms started in 1990. The nationalisation of education policy and the significantly lower level of scholarisation in higher education compared to the countries of 
North America and Western Europe should be particularly highlighted (UNESCO, 2009). Thus, it is interesting to compare the course that the pluralisation of public services has taken during the time of transformation, as it becomes clear why having a choice in higher education system has been appealing. This stage in the education system is not obligatory, which means that there is no necessity to provide the possibility to learn for all interested parties. However, one notices a greater interest in higher education during the phase of transformation, and a question thus arises about how individual sectors will react to the growing demand for educational services.

To accomplish the research goal, the following research questions were posed: 1. What kind of institutions (public, non-public) operate in the area of higher education in the analysed countries? 2. How is higher education financed in these countries? 3. How the process of pluralisation took place in higher education in the analysed countries? 4. Did the development of the non-public sector in higher education respond to the market demand? Answers to these questions can be found in the following paragraphs of the article.

We propose that the educational boom related to the social aspiration to meet the educational standards of highly developed Western countries forced the pluralisation of higher education. The demand for educational services which the public sector could not satisfy also led to the legal changes allowing for the multi-sectoral approach. This was a decision triggered rather by the necessity to extend access to higher education despite significantly limited public funds, than a well-thought-out action of the state (it must also be noted that these changes were carried out in the context of general system transformation and new solutions were often set up ad hoc, serving only as temporary/current solutions to the problems rather than long-term activities). Non-public entities took the opportunity and have permanently become an inherent element of all states' education systems, while education itself has become a market commodity. This, however, does not mean that the non-public schools have eliminated public universities from the education market. In the article, it will be demonstrated that non-public schools should be considered instead as a supplement to the public offer.

In the article, we use the notion of "non-public schools" (interchangeably with "universities") for the institutions run by the market and non-governmental sectors, "private schools" for schools run by business entities, whereas the term "public schools" is reserved for institutions run by the public sector (including the state).

In this study the comparative method has been introduced, accompanied by the institutional and legal analysis, the historical method as well as the statisti- 
cal quantitative analysis. The public statistics of OECD, the UN, the EU, Poland, the Czech Republic and Romania as well as governmental sources found in the individual countries make up the data presented in this article.

\section{The multi-sectoral approach in social policy directed towards the higher education service market}

To analyse the higher education market formation, the paradigm of multi-sectoral social policy was introduced. This concept assumes that not only the state (the public sector) contributes to social welfare but that the civil sector (nonprofit), the market sector (for-profit), the private, and the informal sector (e.g. a family, neighbour or friend circles) do as well. Thus, the chief characteristic of this concept is the assumption that the entities (public, market, non-governmental, informal) which provide (or produce) services, finance and regulate them, should be diverse (Powell, 2007). The multi-sectoral approach draws attention to various sectors' scope of responsibility for providing services, financing them as well as deciding on the type, scope and payment for the services and, finally, for controlling the process of the services' delivery (Hood et al., 1999; Johnson, 1999; Powell, 2007).

Analyses of European higher education systems show that the services related to education, including higher education, are mostly provided by the public sector. The process concerns all three dimensions - production, financing and regulation of education. The majority of countries, and especially Western Europe is dominated by the higher-education schools run and funded by the public sector, their offer is being supplemented - to a greater or lesser extent - by the non-public higher-education schools dependent on the public sector financing (European Commission, 2007; OECD, 2017). The model in which public and non-public schools are financed mainly by the public sector, but also from private sources (including families) occurs in the majority of European post-communist countries and in some countries of Western Europe. A large share of non-public schools and private funding for education - characteristic for the non-European developed countries, e.g. the USA - occurs only in few European countries, for e.g. in Great Britain and Portugal.

In the analysed countries, the higher education system offers collegiatelevel learning as part of the Bologna model, as well as learning in selected study fields in the system of (5- or 6-year-long) unified studies.

Poland, the Czech Republic and Romania present the model of higher education that is basically characteristic of all European post-communist countries. 
This model includes public and non-public schools, as well as dual financing of higher education studies (from public and private sources).

The multi-sectoral analysis requires reference to:

- institutions providing higher education,

- financing of higher education,

- regulation of higher education.

Regulatory and control issues with regard to higher education belong to the tasks of the state and are implemented by relevant ministries and institutions created specially for this purpose. The dimensions of service provision and financing require a broader discussion, which can be found in the following paragraphs.

\section{Financing systems of higher education in Poland, the Czech Republic and Romania}

As far as the issue of dual financing of higher-education schools is concerned, the main source of funds available in these three countries comes from public resources, primarily from the state's budget. These resources, however, are not distributed equally among public and non-public schools. In principle, they are directed to public higher-education institutions. Non-public schools may obtain subsidies under specific rules, although at a significantly reduced rate in comparison to public schools. In the Czech Republic, this situation refers basically to the schools counted among those in the non-government sector. Tuition fees are the second main stream of funds. This mainly applies to non-public schools, for which tuition is the main source of income; however, paid studies are also offered at public universities.

The latest data from 2014 presented by the OECD indicate that in the Czech Republic $76 \%$ of resources for education came from public sources, whereas in Poland this percentage was $81 \%$. Household expenditures for higher education in the Czech Republic totalled 10\%, in Poland - 16\%, whereas other private sources (support from private entities and non-profit organisations) constituted $14 \%$ and $2 \%$ respectively (OECD 2017, p. 198; OECD analysis did not include Romania). The data suggest that the state plays the major role in education financing. In the Czech Republic, the complementary role belongs to private or non-governmental entities, in Poland, however, to family.

At the same time, it must be highlighted that all public expenditures on education at ISCED 5-6 level in 2014 reached 1.18 GDP in the case of Poland, 0.88 in the Czech Republic, and only 0.68 GDP in Romania, with the average 
for 28 states of the EU of 1.24 and for the USA, 1.75. This means that all of the three discussed countries are situated below the EU average, which is characteristic of the post-communist countries of Central and Eastern Europe. Expenditure in Romania was particularly low. This country, together with Bulgaria and Luxembourg, belongs to the countries with the lowest expenditure on higher education (below 0.7 GDP) (UNESCO, 2017).

In the three analysed countries, apart from specific exceptions, education in non-public schools requires settling a tuition fee. In public schools, education is free, but with two significant reservations. In Poland, full-time studies at public universities are free, while part-time students pay tuition. Tuition in public universities is not different from the tuition in non-public institutions; it depends on the status (prestige) of the university, its popularity, and its location, rather than on whether the school is public or not. In Romania, higher university education is free up to an enrolment number approved annually by the Government, after which students pay. Students who go to state universities either pay tuition or their tuition cost is covered by the state budget. In non-public universities, all students pay tuition fees, unless university senates decide otherwise. We can also see a difference between the levels of tuition fees of public universities versus non-public ones. Since the level of tuition fees is set by the universities themselves, without any national standard or regulation, the value of the fees does not necessarily represent the cost of education, but rather the student's ability to pay or the 'market price' of education.

Students can gain financial support to cover the cost of living through loans or scholarships, whereas their parents can receive financial help in the form of family or tax allowance (European Commission, 2009).

\section{Higher education institutions in Poland, the Czech Republic and Romania}

The analyses demonstrate that the public sector is the strongest in the field of higher education, especially in terms of the number of students. If the number of institutions is taken into account, however, non-public centres predominate in Poland and in the Czech Republic (Table 1). Non-public institutions of higher education can be run for profit by the market sector or by the non-government sector as part of its statutory activity, without gaining profit. 
Table 1. Higher education institutions in 2016

\begin{tabular}{|l|c|c|c|}
\hline \multicolumn{1}{|c|}{ Specification } & Poland & Czech Republic & Romania \\
\hline $\begin{array}{l}\text { Number of higher education institutions in total, } \\
\text { including: }\end{array}$ & 390 & 68 & 97 \\
\hline Public school & 132 & 28 & 56 \\
\hline Non-public school & 258 & 40 & 41 \\
\hline Participation in higher education by ownership sectors: & & & \\
\hline Public sector & $34 \%$ & $41 \%$ & $58 \%$ \\
\hline Private sector & $44 \%$ & $37 \%$ & $0 \%$ \\
\hline Non-profit sector (including churches) & $22 \%$ & $22 \%$ & $42 \%$ \\
\hline Number of students, including: & 1348822 & 347079 & 531586 \\
\hline Students of public school & 1034161 & 315595 & 464642 \\
\hline Students of non-public school & 314661 & 31484 & 66944 \\
\hline
\end{tabular}

Source: Own elaboration based on data ČSÚ, 2017; GUS, 2017; INS, 2017; MNiSW, 2016; MŠMT, 2016.

The schools of the private sector predominate in Poland and constitute $44 \%$ of all higher-education entities. The public sector takes the second place when it comes to the number of schools (34\%), whereas the non-government sector, churches, and religious associations run a significantly smaller number of schools (NGOs run 18\% and churches $4 \%$ ). As far as the legal form of the schools is concerned, in the private sector limited liability companies and natural persons prevail. In the case of the third sector - these are associations and foundations. It is worth noting that particular legal forms do not affect school operations significantly; only the sector running an institution is important here. The schools of the non-profit sector work not for profit but within the lines of their statutory activity. They charge tuition fees, but these are used to provide the educational offer, not to gain profit. Schools run by the private sector, on the other hand, are meant to bring profit. Hence, they strive to present an offer which will sell best and consequently attract more students and more fees.

It is obvious from the number of schools that higher education is perceived as a good business which brings school owners tangible profits. The multi-sectoral approach has become a method for easy and cost-free (from the state's perspective) access to higher education for those who are able to pay. Yet, the question remains whether the state should take the responsibility for keeping the balance between the private, non-governmental, and public spheres. Schools in the market sector are profit-oriented and focused not on the quality of teaching but on the sale of the product. In the end, the number of schools in the private 
sector in Poland indicates that higher education is perceived strictly as good business.

In the Czech Republic, the sector of non-public higher education schools is more balanced. If private schools kept by the market and non-government sector are analysed separately, it turns out that none of them has a significant advantage. The public sector maintains slightly more schools than the private sector (respectively $41 \%$ and $37 \%$ ), whereas non-governmental organisations, having $22 \%$ of schools, are not peripheral to higher education.

In this country, education is also perceived sometimes as a business undertaking, but more non-governmental organisations get involved in ventures related to higher education. Thus, in the Czech Republic, running a higher education business has its aims in social benefit. It is not a popular approach to treat higher education as a commodity to be sold at a profit. As far as the legal forms are concerned, the Czech schools in the private sector are established as joint-stock and limited liability companies. In the case of the non-profit sector's schools, they are required to have the form of a public benefit corporation.

The situation of non-public universities in Romania is different, as in 1993, under the Law on Accreditation of Higher Education Institutions and Recognition of Diplomas, the principle was introduced that universities must act as nonprofit entities. This has prevented the ability to make a profit from educational activities and has created a non-public university sector that is complementary to the public one, not as market competition. Non-public universities in Romania could have taken a distinctive role and offered services different from those in public ones, but the majority of them concentrated on copying the practices from successful public institutions.

\section{Higher education pluralisation process}

Higher education in the analysed countries has undergone significant transformations since the 1990s. Earlier, studies were offered only by the public (state) institutions, and the sphere of higher education was totally controlled by the socialist state. The pluralisation process of higher education began in Poland and Romania in the early 1990s, whereas in the Czech Republic it started in the late 1990s, which was associated with a lower demand for higher education in the initial years of transition.

In Poland, during the period of socialism, only public universities functioned; however, at that time, three higher education schools related to the Church operated. But only when the Higher Education Act was passed in 1990 
was there a real stimulus to introduce changes. The Act allowed for establishing non-public higher-education schools. The non-public school system at lower levels was introduced by virtue of the Education System Act in 1991. Since 1998, vocational higher-education schools have also been launched, both state and non-public.

In Romania, the ability to create non-public schools (at all levels of education) was sanctioned in the constitution adopted in 1991 (art. 32). It guaranteed the autonomy of universities and free education in public schools, so by law state universities were granted the possibility to charge fees for places other than these financed by the state. The issues of tuition fees, private education, structure of the higher education institutions, and university autonomy were regulated in the Law on Education. From the early 1990s, in connection with the demand for higher education, non-public universities began to emerge in an uncontrolled way - in 1993 there were already 66 of them (Reisz, 1997, p. 36) compared to 63 public ones (INS, 2017). This resulted in the 1993 law clarifying the rules for creating universities. The Law of Accreditation of Higher Education Institutions and Recognition of Diplomas not only introduced the accreditation of higher education institutions and the recognition of university diplomas, but also the rule that non-public universities must function as nonprofit organisations (Sadlak, 1994).

In the Czech Republic, the pluralisation process started in 1990 with the School System Act, which permitted the establishment of the private education system. Moreover, the act allowed for the launching of non-public colleges, which were introduced to the system in 1996. Furthermore, the Higher Education Schools Act of 1998 allowed for starting non-public higher-education schools.

The analysis of changes in the system of higher education during the transformation period in the three countries allows for the identification of two second pattern concerns non-public universities, which saw a sharp increase in their number, then its stabilisation or even decline. This process in each country has its own specifics, however.

From 1991 until 2005 and on, we have witnessed the dynamic development of non-public higher-education institutions in Poland. The number of public schools remained unchanged, however, a characteristic feature of the Polish education system is the significant numerical superiority of non-public over public schools, which started in 1996. This trend continues - there are about 2.5 times more non-public schools than public ones, though since 2012 we have been observing a decrease in the number of non-public universities (Fig. 1.). 


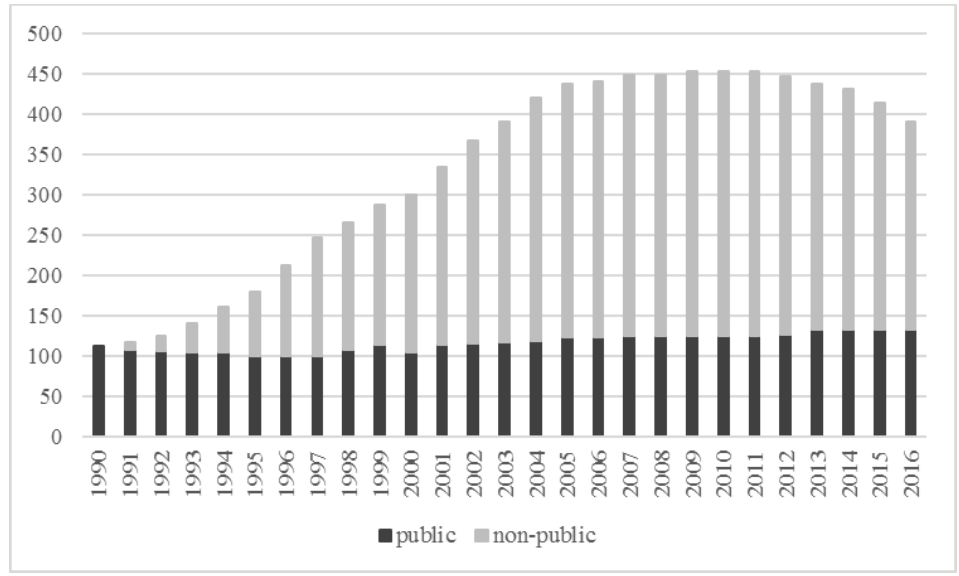

Fig. 1. Public and non-public higher-education schools in Poland Source: Own elaboration based on data GUS, 2017.

In the Czech education system, we can see similar tendencies, although the skew in the number of non-public schools versus public ones is lower than in Poland. The first non-public higher education schools in the Czech Republic did not appear until 2000, and since 2009 we have observed their growth in number. Nowadays, this growth is slowing down (Fig. 2.).

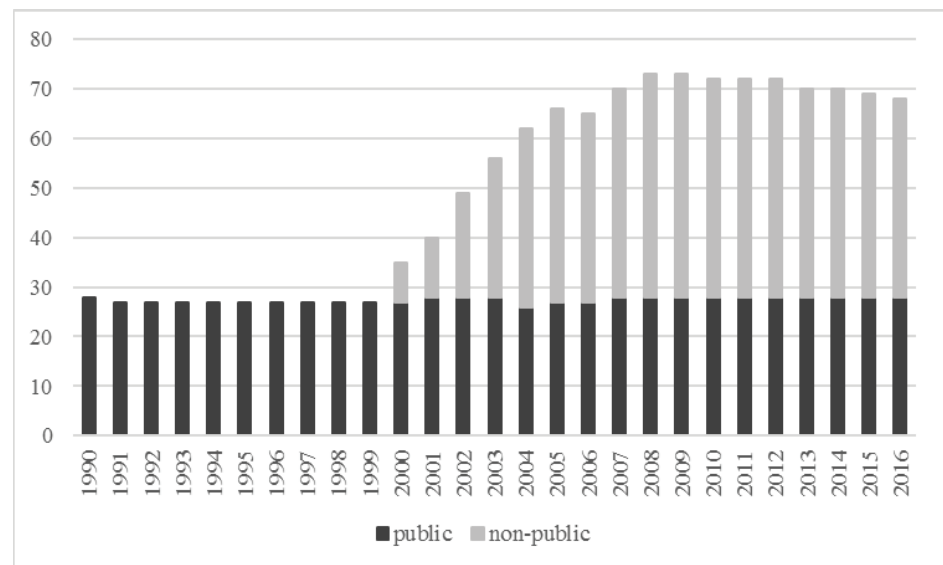

Fig. 2. Public and non-public higher-education schools in the Czech Republic Source: Own elaboration based on data Čsú, 2017. 
In Romania, we observed dynamic growth in the number of non-public schools from the early 1990s to 2002. Romania faced a growing demand for higher education at the beginning of the 1990s along with an inability of public universities to respond due to their financial and organisational incapacity. What is more, the lack of legislation around the establishment and functioning of non-public universities led to the introduction of the principle "what is not forbidden is allowed' by private entrepreneurs (Nicolescu, 2001). In 1993, the legislation regulating the establishment and functioning of universities was finally introduced and some entities ended their activity (Nicolescu, 2007). Since 2002, we have observed a decrease and, recently, stabilisation in the number of non-public universities. In Romania, however, we do not observe a significant numerical advantage of non-public schools over public ones - the number of both types of institutions is very similar (Fig. 3.).

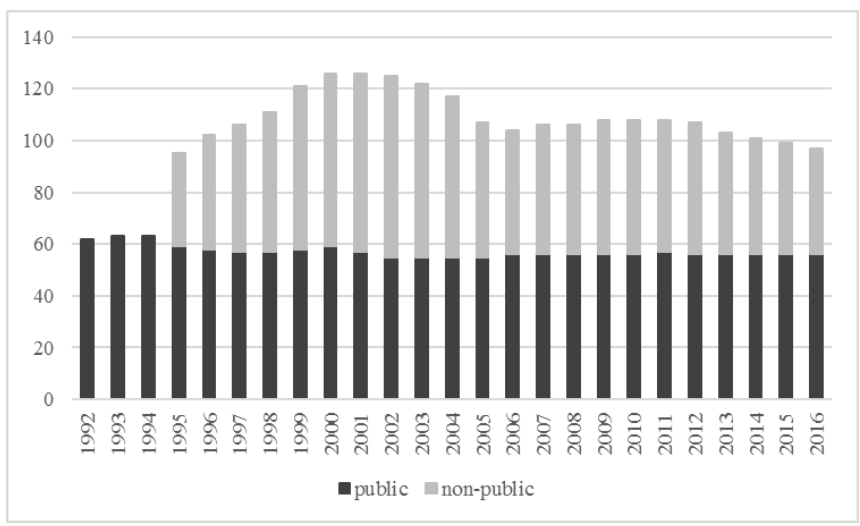

Fig. 3. Public and non-public higher-education schools in Romania

Source: Own elaboration based on data INS, 2017.

Note: The official statistics indicate non-public schools only since 1995.

The trends related to the growth of non-public schools in Poland, the Czech Republic and Romania are confirmed by the analysis of the number of nonpublic school students (Fig. 4.); in this respect, one can also point to specific features of the different educational systems.

In 2016 in Poland, 23\% of students studied in non-public higher-education institutions, while in Romania and the Czech Republic this percentage was significantly lower: $13 \%$ and $10 \%$ respectively. The share of students in non-public 


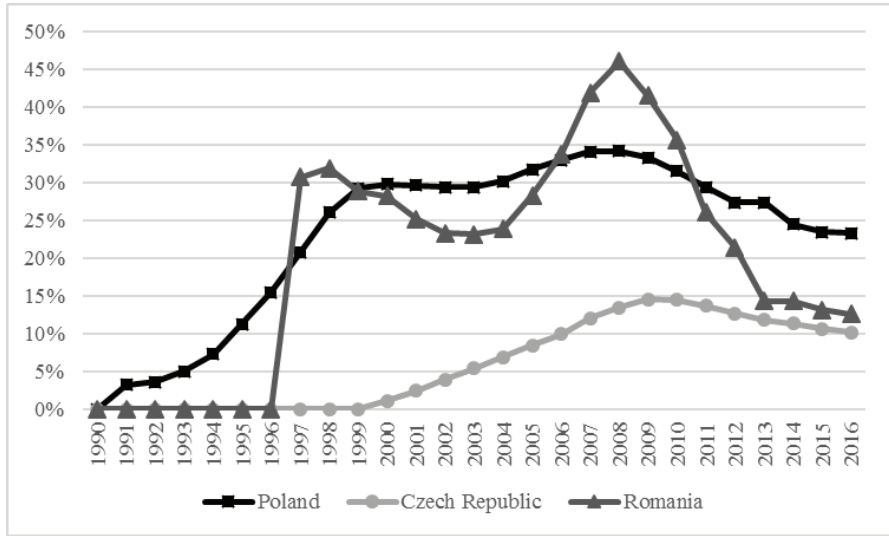

Fig. 4. Students of non-public schools as the percentage of students in total Source: Own elaboration based on data Čsú, 2017; GUS, 2017; INS, 2017.

institutions compared to the total number of students is the highest in Poland among the three analysed countries. It should be noted that though there are 2.5 times more non-public universities than public ones in Poland, far more students study at public universities ( $77 \%$ of the total). This indicates that although there are many non-public universities, they are small entities that offer education usually in a limited number of fields of study. It should also be stressed that the percentage of students in non-public schools in Poland was growing dynamically until 1999, stabilised, and since 2008 has decreased by 11 percentage points.

In the Czech Republic, the commencement of non-public schools' operations triggered the dynamic growth in the percentage of students learning in such schools. This growth, however, was stabilised at the level of $14-15 \%$ in 2008-2011, but since 2011 this share has been declining.

The most dynamic situation in the number of students in non-public institutions versus the total number of students is presently found in Romania. An increase in the number of students (up to $32 \%$ in 1998) was observed, followed by a decline to $23 \%$ in $2002-2003$, then a dramatic growth to $46 \%$ in 2008 , and another decline in subsequent years. The declining share and the decreasing number of students in non-public universities in Romania was explained by both demographic phenomena and the economic recession that led to lower incomes, which greatly affected the ability of paying tuition fees (Drâgoescu, 2013). What is more, the private sector has a lower degree of perceived legiti- 
macy compared to the public one. After introducing the fee system in public institutions, many students choose to study at a public university. The increase in number of paid master's programs offered by public universities, including easy access without entrance exams, was largely caused by non-public university graduates preferring to pay for a program in the public university in order to get higher credibility and a degree from a renowned university (Nicolescu, 2005).

The main problem related to the pluralisation of higher education in the analysed countries was, because of the lack of public funds, leaving non-public higher schools to the free market. The creation of higher education institutions, perceived as a good business, began to enjoy great popularity, which resulted in the creation of many institutions, often not well prepared to educate students in accordance with the assumptions of the university education idea (Nussbaum, 1998, 2016). In addition, the reluctance to reform public higher schools created two alternative education systems.

\section{The growth of the non-public education system as a response to market demand}

The growth of the knowledge-based economy involves enhancing the status of higher education and thus, a systematic increase in the number of students. Since the 1970s, the number of students in the world has grown from less than 30 million to over 150 million (UNESCO, 2009, p. 10).

We have been observing an increasing demand for higher education also in Poland, the Czech Republic and Romania since the beginning of the 1990s. On the one hand, this is an effect of the authorities' policy of pursuing an increase in the participation of those with secondary and higher education in the education structure; on the other hand, it results from the involvement of citizens themselves, who discern the need to learn or supplement their knowledge. In these countries, in the 1990s, higher education was perceived as a precaution against unemployment. Today, it does not guarantee the security of employment; nevertheless, for the younger generation, higher education is becoming almost a prerequisite of success on the labour market. Studies indicate that higher education still limits the risk of unemployment and supports professional activity (OECD, 2011). Looking at the percentage of students among those aged 20-24, one can clearly see more interest in higher education (Fig. 5). In 1990, in the Czech Republic, $17 \%$ of people belonging to this age group were students, whereas in Poland they constituted 16\%, and in Romania only $11 \%$. In 2016 the percentage was $57 \%, 59 \%$ and $38 \%$ respectively. An increase in the number of students 
among young people was particularly evident until 2008-2011, after which the share of students is stabilised. In Romania in recent years a significant decrease in the share of students in the population of young people has been observed, which is associated with the recession and the high cost of studying.

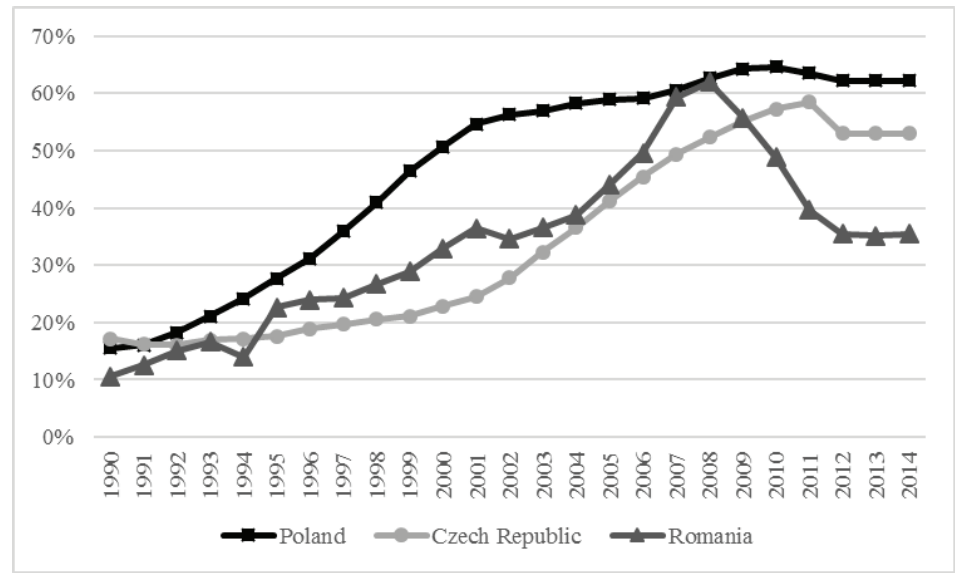

Fig. 5. Students as the percentage of population at the age of 20-24

Source: Own elaboration based on data ČSÚ, 2017; GUS, 2017; INS, 2017.

In Poland and the Czech Republic, demography supported the demand for education. Until 2005 in Poland and until 1998 in the Czech Republic, there was an increase in the population of people aged 20-24, i.e. young people, who most often take up studies. Moreover, many people aged 30 to 40 were interested in rounding up their education. At the same time, the current demographics of the three analysed countries have become a major challenge for the higher education market. Social and economic problems of the transition period have caused a decrease in the fertility rate and a demographic decline is already noticeable at universities. In addition, the share of university students is so high that its further growth should not be expected. Universities, especially non-public ones, must be prepared for such a specific circumstance.

The dynamic growth of higher education which has taken place since the 1990s is related primarily to the market demand, and this is true both for the public as well as the non-public sector. In the case of the public sector, we will first examine the expansion of the offer of existing public schools. The number of free places was increased and new fields of study appeared, which brought 
more students. In the case of the non-public sector, the growth of free places at universities resulted from the establishment of new education institutions and the extension of their offer. The study fields that were in high demand after 1990 (economics, business, law, journalism, etc.) did not require any special equipment and consequently no expensive accoutrements; for this reason, non-public institutions in Central and Eastern European countries appeared mostly in these fields. Taken together, within 15-20 years the increase in the number of students was very high. For example: in 1990, in Poland, almost 404,000 people studied, while in 2005 the peak of over 1.9 million was reached. In the Czech Republic, in 1990, the number of students slightly exceeded 118,000, but in 2010 this number more than tripled to 396,000. In Romania, in 1990, 193,000 students were recorded, while the peak was reached in 2007 with as many as 907,000 (ČSÚ, 2017; GUS, 2017; INS, 2017).

This great increase in the interest in studying had to be dealt with. Although public higher-education institutions greatly extended their offer, they still were not able to provide free places for so many applicants; hence, other sectors needed to take action. When the state permitted creating non-public institutions, private and non-governmental entities responded to the market demand by establishing new institutions. At the same time, the system of requirements for non-public higher education institutions in terms of professionalism of education and linking education and research was not satisfactory, which resulted in the creation of many schools focused exclusively on educating the greatest possible number of students at the lowest possible costs.

Additional free places, new fields of study and specialities, convenient mode of studying, centres in small towns - with these factors, the non-public sector won clients. Unfortunately, in the case of the majority of non-public schools, high-quality teaching was not among the factors attracting students. Generally, their offer attracted people who did not qualify for free studies in public higher-education institutions or were working and wanted to round up their education. Thus, the product was tailored to their intellectual capabilities. At the beginning their didactic base also left a lot to be desired. Highereducation schools often operated in rented buildings not adjusted to students' needs and had no specialist rooms or laboratories. On account of the decline in interest in non-public higher education institutions observed in recent years, resulting from the demographic low and the development of public universities' offer, many non-public universities have improved the quality and conditions of education. Some non-public higher schools in these countries do live up to the standard of the best public schools. 


\section{Conclusion}

The conducted analysis shows that the liberalisation of the higher education system in selected post-communist countries was a response to the new market demand. The process led also to the creation of the model in which both public and non-public universities operate, involving public and private funding sources. The analysis allows for drawing the following conclusions:

1. Before 1989 in Poland, the Czech Republic and Romania higher education was conducted and financed by the public sector. Only during the transformation process the commercialisation of education and pluralism in higher education began. The course of changes took into account the multi-sectoral approach, meaning that the non-profit, market and private sectors can provide and finance educational tasks.

2. The pluralisation of educational services in the field of higher education system should be deemed a strength of higher education in Poland, the Czech Republic and Romania. The private and non-government sectors sprang up as a response to the market demand related to the educational boom which took place shortly after the beginning of the transformation process as the public higher-education institutions were not able to offer learning to all interested parties. The governments did not have an idea how to solve the problem of the increased interest in higher education, so they applied the simplest solution and allowed non-public entities to act on market principles, without adequate support for either private schools or their students.

3. In all of the analysed countries, the public sector dominates in higher education. In the post-communist countries, unlike in the majority of Western European countries, the larger share of the market sector and non-profit organisations in the higher education is noticeable. In these countries, also a greater share of the private funding of higher education can be observed, including household budgets. So, there is a noticeable dissimilarity of the post-communist countries in comparison to the traditional European welfare states, particularly those of the social democratic orientation. The implementation of multi-sectoral solutions does not, however, result from the adopted model of higher education, but from the limited financial resources. Therefore, private institutions in these countries have been relying mainly on students' fees as the source of funds and they generally educate significantly less students than public universities. 
4. The pluralisation of higher education brings numerous benefits. Apart from the aforementioned provision of educational services to the clients seeking them, increased competition, diversified education offers and its adjustment to the requirements of the labour market, innovation and better access to education through newly launched institutions in smaller towns, must be emphasised. Naturally, this does not mean that non-public schools are flawless. Especially in Poland and Romania, where non-public universities have been established since the beginning of the transformation, they have often been accused of low quality of teaching, irregularities in the teaching process, and deficiencies in didactic staff or technical facilities. On the one hand, pluralisation in higher education broadened the educational offer, but on the other, it resulted in lowering the quality of education and the requirements for students.

5. It is still difficult for non-public higher-education institutions to compete with public ones which can boast of a long tradition, high quality of teaching, well-qualified staff, as well as the didactic base. The oldest public institutions in the Czech Republic and Poland, Charles University in Prague and the Jagiellonian University in Krakow, were established in the $14^{\text {th }}$ century; the oldest university in Romania, the Alexandru Ioan Cuza University, was established in 1860, while the oldest non-public institutions have been operating for approximately 20 years. Still, it does not mean that non-public higher education schools are exclusively schools of the second division. Many of them managed to gain recognition. Stability in the society's interest in higher education and the population decline will modify the demand for non-public education in market terms in years to come. This will be a chance for these higher education schools to stabilise and strengthen their position on the market.

6. Post-transformation European Countries were not ready for rapid, simultaneous liberalisation and privatisation of industry, but also social services previously financed from public sources. The best exemplification of this state of affairs was the qualitative chaos that prevailed within the higher education system. This does not mean that the marketisation process of higher education did not occur at the same time in other European countries. The difference, however, was that for the rest of Europe marketisation, which was inscribed in contemporary phase of capitalism, was just another development strategy and for countries 
after the transition it was a total qualitative as well as systemic change for which they were not ready.

\section{References:}

Act on Higher Education of 1990. PL.1990.65.385 et seq.

Act on Education System of 1991. PL.2004.256.2572 et seq.

Act on Higher Vocational Schools of 1997. PL.1997.96.590 et seq.

Act on the System of Primary, Secondary and Vocational Education of 1984. Cz.1984.29 et seq.

Act on Higher Education and Amendments to Other Acts of 1998. Cz.1998.111 et seq.

Amaral, A. (2012). Foreword (p. IX-XIII). In: Neave G. (ed.). The Evaluative State, Institutional Autonomy and Re-engineering Higher Education in Western Europe. The Prince and His Pleasure. Hampshire: Palgrave Macmillan.

Bok, D. (2004). Universities in the Marketplace: The Commercialization of Higher Education. Oxford: Princeton University Press.

ČSÚ - Český Statistický Úřad. (2017). https://www.czso.cz/

Constitution of Romania of 1991. RO.1991.233.

Drâgoescu, R. M. (2013). Changes in Romanian higher education after 1990. Romanian Statistical Review, 3, pp. 28-36.

European Commission (2009). Key Data on Education in Europe 2009. Brussels: Education, Audiovisual and Culture Executive Agency Eurydice.

European Commission (2007). Key Data on Higher Education in Europe. 2007 Edition. Luxembourg: Office for Official Publications of the European Communities.

GUS - Główny Urząd Statystyczny (2017). http://stat.gov.pl.

Heller, D. E. (2011). The States and Public Higher Education Policy: Affordability, Access, and Accountability. Baltimore: The Johns Hopkins University Press.

Hood, C. at al. (1999). Regulation Inside Government. Waste-watchers, Quality Police and Sleaze-busters. Oxford: Oxford University Press.

INS - Institutul National de Statistica (2017). http://www.insse.ro/cms/ro.

Johnson, N. (1999). Mixed Economies of Welfare. Hemel Hempstead: Prentice Hall.

Law on Education of 1995. RO.1995.84 et seq. 
Law on Accreditation of Higher Education Institutions and Recognition of Diplomas of 1993. RO.1993.88 et seq.

Lovell, Ch. D., Larson, T. E., Dean, D. R., \& Longanecker D. L. (2012). Public Policy and Higher Education. New York: 2012.

Marginson, S. (2007). The public/private divide in higher education: A global revision. Higher Education, 53, pp. 307-333.

MNiSW - Ministerstwo Nauki i Szkolnictwa Wyższego (2017). System informacji o szkolnictwie wyższym. Warszawa: MNiSW.

MŠMT - Ministerstvo školství, mládeže a tělovýchovy (2017). Přehled soukromých vysokých škol. Praha: MŠMT ČR.

Neave, G. (2012). Institutional Autonomy and Re-engineering Higher Education in Western Europe. The Prince and His Pleasure. Hampshire: Palgrave Macmillan.

Neave, G. (1998). The Evaluative State Reconsidered. European Journal of Education, 33, pp. 265-284.

Nicolescu, L. (2001). Contribution to Higher Education in Transition towards the Market Economy: the Case of Romania. In: Luihto K. (ed.). Ten Years of Economic Transformation. Studies in Industrial Engineering and Management, 16, pp. 253-281.

Nicolescu, L. (2005). Private versus Public in Romania: Consequences for the Market. International Higher Education, 39, pp. 12-13.

Nicolescu, L. (2007). Institutional Efforts for Legislative Recognition and Market Acceptance: Romanian Private Higher Education (pp. 201-222). In: Slantcheva S., \& Levy D.C. (eds.). Private Higher Education in Post-Communist Europe. In Search of Legitimacy. New York: Palgrave Macmillan.

Nussbaum, M. (1998). Cultivating Humanity: A Classical Defense of Reform in Liberal Education. Harvard: Harvard University Press.

Nussbaum, M. (2016). Not for Profit: Why Democracy Needs the Humanities. Princeton: Princeton University Press.

OECD (2017). Education at a Glance 2017: OECD Indicators. Paris: OECD Publishing, DOI: http://dx.doi.org/10.1787/eag-2017-en.

Paulsen, M. B., \& Smart J. C. (2002). The Finance of Higher Education: Theory, Research, Policy, and Practice. New York: Agathon Press.

Potulicka, E. (2010). Neoliberalne uwikłania edukacji. Kraków: Oficyna Wydawnicza „Impuls".

Potulicka, E. (1996). Reforma edukacji wedtug modelu demokracji rynkowej oraz z perspek- 
tywy demokracji liberalno-etycznej i socjaldemokratycznej. Poznań-Toruń: Wydawnictwo Edytor.

Powell, M. (2007). Introduction: the mixed economy of welfare and the social division of welfare (pp. 1-21). In: Powell M. (ed.). Understanding the Mixed Economy of Welfare. Bristol: Policy Press.

Reisz, R. D. (2007). Legitimacy Discourse and Mission Statements of Private Higher Education Institutions in Romania (pp. 135-155). In: Slantcheva S., \& Levy D. C. (eds.). Private Higher Education in Post-Communist Europe. In Search of Legitimacy. New York: Palgrave Macmillan.

Reisz, R. (1997). Private higher education in Romania. Tertiary Education and Management, 3, pp. 36-43.

Sadlak, J. (1994). The emergence of a diversified system: the state/private predicament in transforming higher education in Romania. European Journal of Education, 29(1), pp. 13-23.

Teixeira, P. N., \& Dill D. D. (2011). Public Vices, Private Virtues?: Assessing the Effects of Marketization in Higher Education. Rotterdam: Sense Publishers.

UNESCO. (2009). Global Education Digest 2009. Comparing Education Statistics Across the World. Montreal: UNESCO Institute for Statistics.

UNESCO. (2017). Government expenditure on education as a percentage of GDP. http:// data.uis.unesco.org/index.aspx?queryid=181\#.

Weisbrod, B. A., Ballou, J. P., \& Asch, E. D., Mission and Money: Understanding the University. Cambridge: Cambridge University Press. 